\title{
ANALISIS FINANCIAL DISTRESS MENGGUNAKAN ANALISIS SURVIVAL
}

\author{
Komang Ridha Pranita \\ Program Studi Akuntansi Universitas Telkom \\ ridhapra@students.telkomuniversity.ac.id \\ Farida Titik Kristanti \\ Program Studi Akuntansi Universitas Telkom \\ faridatk@telkomuniversity.ac.id
}

\begin{abstract}
Abstrak: Analisis Financial Distress Menggunakan Analisis Survival. Penelitian ini memiliki tujuan untuk mengetahui pengaruh rasio likuiditas, leverage, salesgrowth, ukuran perusahaan, kepemilikan manajerial, dan kepemilikan institusional terhadap financial distress. Populasi penelitian di sektor industri dasar dan kimia dan sektor indutri barang konsumsi yang terdaftar di Bursa Efek Indonesia Periode 2009-2018. Teknik pengambilan sampel dengan teknik purposive sampling dan diperoleh 63 perusahaan atau sampel. Teknik analisis yang digunakan ialah teknik analisis survival. Hasil penelitian: likuiditas, leverage, salesgrowth, ukuran perusahaan, kepemilikan manajerial, dan kepemilikan institusional berpengaruh secara simultan terhadap financial distress. Likuiditas, leverage, dan kepemilikan manajerial tidak berpengaruh terhadap financial distress. Salesgrowth dan ukuran perusahaan berpengaruh negatif signifikan terhadap financial distress, dan kepemilikan institusional berpegaruh positif signifikan terhadap financial distress.
\end{abstract}

Kata kunci. Likuiditas; Leverage; Salesgrowth; Ukuran Perusahaan; Kepemilikan Manajerial; Kepemilikan Institusional; Financial Distress

Abstract: Financial Distress Analysis Using Survival Analysis. This research aims to predict the effect of liquidity ratio, leverage ratio, salesgrowth ratio, company size, managerial ownership, and institutional ownership of financial distress. The population in the research sector is the basic industry and chemical and consumer goods industry listed on the Indonesia Stock Exchange period 2009-2018. In sampling using techniques purposive sampling and obtained 63 companies or samples. The analytical techniques used in research are survival analysis. Research results: Liquidity ratio, leverage ratio, salesgrowth ratio, company size, managerial ownership, and institutional ownership of simultaneous effect on financial distress. Liquidity ratio, leverage ratio, managerial ownership has no effect on the financial distress. Salesgrowth ratio and the company's size have significant negative effect on the financial distress, and institutional ownership has a significant positive effect on the financial distress.

Keywords: Liquidity; Leverage; Salesgrowth; Company Size; Managerial Ownership; Institutional Ownership; Financial Distress

\section{PENDAHULUAN}

Perusahaan didirikan bertujuan untuk menghasilkan laba. Laba yang dihasilkan akan digunakan untuk meningkatkan kinerja perusahaan dan juga untuk mempertahankan keberlangsungan usaha perusahaan dalam jangka waktu yang lama. Dalam mempertahankan usahanya, perusahaan harus bersaing dengan perusahaan kompetitor lainnya dan bersaing juga dengan perkembangan perubahan berbagai aspek di Indonesia yang mendorong perusahaan agar melakukan inovasi terhadap produk yang diproduksi sehingga nantinya perusahaan dapat mempertahankan kestabilitasan perusahaan. Selain itu, perusahaan yang menghasilkan laba tinggi pasti akan menarik perhatian para investor untuk melakukan 


\section{Nominal: Barometer Riset Akuntansi dan Manajemen}

P-ISSN: 2303-2065 E-ISSN: 2502-5430

Volume 9 No 2 (2020)

investasi. Investor akan menganalisis kondisi perusahaan sebelum pengambilan keputusan untuk berinvestasi. Jika perusahaan tidak dapat mempertahankan hal-hal tersebut, maka kemungkinan perusahaan akan mengalami kesulitan keuangan atau financial distress.

Kesulitan keuangan (financial distress) ialah kondisi bagi perusahaan dimana perusahaan tidak dapat memenuhi kewajibannya, jika kondisi tersebut terjadi maka perusahaan akan mengalami kebangkrutan (Kristanti, 2019:3). Definisi lainnya, financial distress merupakan suatu proses menurunnya posisi keuangan sebelum perusahaan bangkrut atau mengalami likuidasi (Widhiari \& Merkusiwati, 2015). Financial distress sangat perlu diwaspadai dan diantisipasi karena dapat mengganggu aktivitas operasional perusahaan (Carolina et al., 2017). Financial distress sangat perlu dikhawatirkan karena dapat menimbulkan permasalahan yang sangat besar bagi perusahaan, maupun investor perlu untuk mengetahui indikasi awal kondisi perusahaan sehingga pihak manajemen dapat memberikan keputusan yang tepat atau melakukan tindakan korektif (Kristanti, Herwany, et al., 2016). Financial distress tidak saja merusak sistem keuangan perusahaan, tetapi dapat merusak organisasi perusahaan secara menyeluruh dan hilangnya sumber keuangan perusahaan dan sumber daya manusia bisa menyebabkan perusahaan likuidasi (Kristanti, 2019:3)

Financial distress dapat terjadi bagi seluruh jenis perusahaan baik itu perusahaan besar maupun perusahaan kecil. Pengukuran perusahaan yang mengalami financial distress menggunakan earning per share (EPS) negatif. EPS digunakan karena EPS dapat menggambarkan keuntungan yang diperoleh perusahaan, sehingga jika perusahaan memiliki EPS negatif maka akan jelas perusahaan mengalami kerugian dalam usahanya (Sunarwijaya, 2017). Penelitian ini menggunakan variabel dummy, yaitu perusahaan yang memiliki EPS positif diberi nilai 0 , jika perusahaan memiliki EPS negatif maka diberi nilai 1 (Kristanti, Rahayu, et al., 2016)

Penelitian ini menggunakan perusahaan pada sektor industri dasar kimia dan sektor industri barang konsumsi yang terdaftar di Bursa Efek Indonesia. Sektor tersebut merupakan sektor manufaktur, dimana sektor manufaktur termasuk sektor penguat bagi perekonomian di Indonesia. Kementerian Perindustrian mencatat industri manufaktur merupakan salah satu sektor yang menyumbang cukup signfikan bagi total investasi di Indonesia dan menurut Menteri Perindustrian Airlangga Hartanto menyampaikan bahwa sektor industri manufaktur merupakan tulang punggung bagi pertumbuhan ekonomi nasional dan 
menjadi sektor andalan dalam memacu pemerataan terhadap pembangunan dan kesejahteraan masyarakat yang inklusif (www.kemenperin.go.id).

Pada gambar 1, dapat dilihat bahwa jumlah perusahaan pada sektor industri dasar dan kimia dan sektor industri barang konsumsi periode 2009-2018 memiliki perbedaan. Perusahaan pada sektor industri barang konsumsi yang memiliki EPS negatif cukup rendah. Sementara perusahaan pada sektor industri dasar kimia memiliki grafik yang tinggi berarti pada sektor tersebut, banyak perusahaan yang memiliki EPS negatif. Jika perusahaan terus memiliki nilai EPS yang negatif selama berturut-turut setiap tahun maka kemungkinan akan terjadinya kondisi financial distress bagi perusahaan tersebut atau kemungkinan hal buruk terjadi perusahaan akan mengalami kebangkrutan.

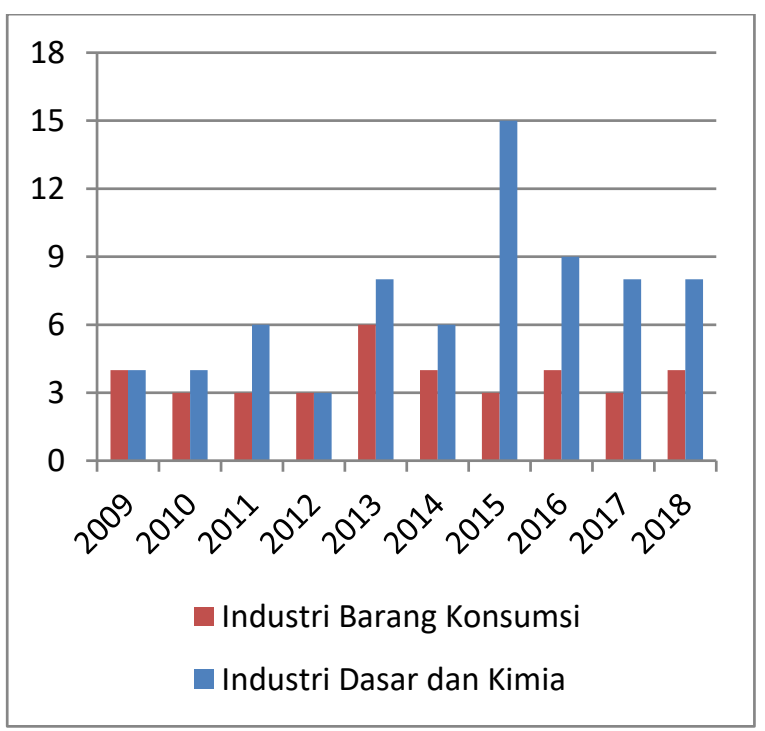

Sumber: BEI 2009-2018 (data diolah penulis,2020)

Gambar 1. Jumlah Perusahaan Yang

Mempunyai Nilai EPS Negatif Pada Industri
Dasar dan Kimia dan Industri Barang Konsumsi Periode 2009-2018

\section{KAJIAN LITERATUR}

\section{Teori Keagenan (Agency Theory)}

Teori yang melandasi yaitu teori agensi (agency theory). Teori agensi, hubungan keangenan ialah perjanjian antara principal dengan agent. Perjanjian tersebut dilakukan oleh principal tetapi harus diketahui dan disetujui oleh agent (Jensen \& Meckling, 1976). Principal adalah pemegang saham dan agent adalah manajemen perusahaan. Sehingga teori keagenan dapat menggambarkan jika agent memiliki keunggulan informasi dibandingkan dengan principal yang disebut asimetri informasi dan memiliki kepentingan yang berbeda (conflict of interest), dengan begitu dapat memungkinkan bahwa agent akan melakukan tindakan yang menguntungkan dirinya tetapi merugikan principal. Maka dari hal tersebut dapat memunculkan beban akibat tindakan tersebut menjadi agency costs. Hal tersebut tidak saja terkait manajemen dengan pemegang saham saja, tetapi siapa pun bisa selama kedua belah pihak terikat dalam kontrak tersebut (Gudono, 2017:147)

\section{Likuiditas terhadap Financial Distress}

$$
\text { Rasio likuiditas menunjukkan }
$$
kemampuan perusahaan dalam mendanai aktivitas operasional perusahaan dan 


\section{Nominal: Barometer Riset Akuntansi dan Manajemen \\ P-ISSN: 2303-2065 E-ISSN: 2502-5430 \\ Volume 9 No 2 (2020)}

melunasi kewajiban jangka pendek perusahaan (Widarjo \& Setiawan, 2009). Likuditas menunjukkan kemampuan perusahaan untuk membayar kewajiban finansial jangka pendek tepat pada waktunya (Carolina, Marpaung, \& Pratama, 2017). Jika likuiditas perusahaan tinggi maka akan dapat mengurangi terjadinya financial distress (Kristanti \& Effendi, 2017)

Rasio likuiditas menjelaskan bagaimana perusahaan mampu membayar kewajiban lancar pada waktu yang tepat. Jikalau perusahaan memiliki kewajiban lancar terlalu besar itu akan berdampak pada besarnya total kewajiban perusahaan untuk segera dilunasi. Jika tidak segera dilunasi satu-persatu kewajibannya yang sudah jatuh tempo akan mengakibatkan perusahaan mengalami financial distress meningkat.

$\mathrm{H}_{1}=$ Likuiditas berpengaruh arah negatif terhadap financial distress

\section{Leverage terhadap Financial Distress}

Rasio leverage merupakan rasio yang digunakan untuk mengukur sejauhmana aktivitas perusahaan dibiayai oleh hutang perusahaan (Moleong, 2018). Financial distress dapat dimulai dari ketidakmampuan perusahaan memenuhi kewajibannya, baik kewajiban jangka pendek yang termasuk dalam kategori likuiditas dan juga termasuk kewajiban dalam kategori solvabilitas (Aisyah et al., 2017). Perusahaan yang memiliki total hutang lebih besar dari total aktiva maka perusahaan akan kemungkinan memiliki risiko gagal bayar kewajibannya dan dapat berakibat pada tahun selanjutnya (Halim et al., 2018). Perusahaan diharuskan mengatur aktiva perusahaan agar dapat melunasi kewajibannya dengan tepat waktu dan dapat meminimalisir risiko gagal bayar bagi perusahaan. Apabila kewajiban perusahaan berjumlah sangat besar itu akan mempengaruhi kestabilan perusahaan sehingga dapat membuat perusahaan mengalami financial distress meningkat.

$\mathrm{H}_{2}=$ Leverage berpengaruh positif arah terhadap financial distress

\section{Salesgrowth terhadap Financial Distress}

Salesgrowth ialah rasio yang mencerminkan kemampuan perusahaan untuk meningkatkan penjualannya dari waktu ke waktu (Widarjo \& Setiawan, 2009). Tingginya nilai pertumbuhan penjualan bagi perusahaan itu menunjukkan bahwa kondisi perusahaan stabil dan diharapkan dapat terhindar dari financial distress dan rasio ini dapat juga dijadikan gambaran bagi perusahaan untuk lebih meningkatkan kembali penjualan. Salesgrowth memperlihatkan potensi perusahaan dalam meningkatkan penjualan dari tahun ke tahun. Pemasaran dan penjualan yang meningkat menandakan bahwa strategi yang digunakan perusahaan berjalan dengan baik. 
Peningkatan tersebut mencerminkan laba yang akan diperoleh bagi perusahaan. Dengan begitu, kemungkinan perusahaan mengalami financial distress semakin kecil.

$\mathrm{H}_{3}=$ Salesgrowth berpengaruh arah negatif terhadap financial distress

\section{Ukuran Perusahaan terhadap Financial}

\section{Distress}

Ukuran perusahaan adalah skala yang menunjukkan besar kecilnya suatu perusahaan (Gobenvy, 2014). Ukuran perusahaan yang memiliki total aset besar berarti perusahaan tersebut memiliki kemampuan dalam membayar kewajiban tepat waktu yang akan membuat perusahaan dapat mempertahankan keberlangsungan perusahaannya (Kristanti \& Effendi, 2017). Total aktiva yang besar akan mempermudah perusahaan melakukan diversification dan membuat perusahaan semakin kecil mengalami financial distress. Dapat dikatakan bahwa ukuran perusahaan yang besar akan semakin kecil memperkecil peluang perusahaan terindikasi financial distress.

$\mathrm{H}_{4}=$ Ukuran Perusahaan berpengaruh arah negatif terhadap financial distress

Adapun faktor eksternal yang dapat mempengaruhi serta memprediksi financial distress yaitu tata kelola perusahaan atau corporate governance yang diterapkan di perusahaan. Menurut (Sunarwijaya, 2017) kesuksesan suatu perusahaan dapat ditentukan oleh karakterisitik strategis dan manajerial perusahaan, strategis tersebut mencakup bagaimana tata kelola keuangan dan non keuangan perusahaan. Menurut (Kristanti, 2019:21) tata kelola perusahaan merupakan pertimbangan bagaimana para dewan dan komisaris beroperasi, bagaimana dalam menentukan performansi perusahaan, dan hubungan kebijakan tenaga kerja dengan performansi perusahaan serta peran dari para pemegang saham.

\section{Kepemilikan Manajerial terhadap Financial Distress}

Kepemilikan manajerial adalah kepemilikan saham perusahaan yang dimiliki oleh manajer perusahaan tersebut. Kepemilikan manajerial dapat menyelaraskan antara kepentingan manajer dan kepentingan investor sehingga diharapkan mampu menjadi mekanisme yang dapat mengurangi masalah keagenan antara manajemen dan investor (Sunarwijaya, 2017). Kepemilikan manajerial diukur menggunakan saham yang dimiliki oleh manajer dibandingkan dengan seluruh saham yang beredar. Dapat disimpulkan, semakin banyak saham kepemilikan manajerial maka meningkat tinggi pula pengawasan terhadap kebijakan pengambilan keputusan bagi perusahaan dan diharapkan akan berdampak baik bagi kinerja operasional perusahaan, 
serta dapat mengecilkan peluang financial distress.

$$
\mathrm{H}_{5}=\text { Kepemilikan manajerial }
$$
berpengaruh arah negatif terhadap financial distress

\section{Kepemilikan Institusional terhadap Financial Distress}

Kepemilikan institusional merupakan saham yang terdapat dimiliki oleh kepemilikan institusi atau lembaga bank atau asuransi. Kepemilikan institusional merupakan kepemilikan saham oleh lembaga dari eksternal (Cinantya \& Merkusiwati, 2015). Dengan adanya kepemilikan saham institusional diharapkan dapat meningkatkan efisiensi penggunakaan aktiva perusahaan serta terkait pengawasan secara efektif atas keputusan manajemen perusahaan tersebut (Sunarwijaya, 2017). Kepemilikan institusional diukur menggunakan saham yang dimiliki institusional dibandingkan dengan seluruh saham yang beredar. Kepemilikan saham institusional diharapkan dapat meminimalisir masalah keagenan antara pemegang saham dan menajemen perusahaan. Kepemilikan institusional yang berarti pengawasan terhadap kinerja operasional perusahaan akan semakin ketat karena lembaga-lembaga tersebut ikut adil dalam pengambilan keputusan bagi perusahaan. Hal tersebut menandakan bahwa apabila kepemilikan institusional semakin besar akan memperkecil kemungkinan peluang untuk financial distress.

$\mathrm{H}_{6}=$ Kepemilikan institusional berpengaruh arah negatif terhadap financial distress

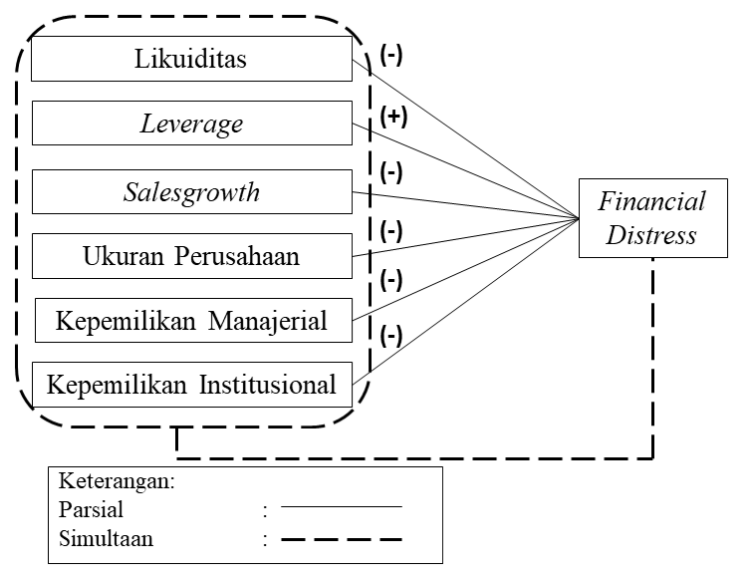

Gambar 2. Kerangka Pemikiran

\section{METODE PENELITIAN}

Metode penelitian yang digunakan yaitu bersifat kausal yang bertujuan untuk mengetahui hubungan sebab-akibat dalam menguji pengaruh antar variabel dependen terhadap variabel indepeden (Sudaryono, 2017:89). Data menggunakan data sekunder berupa laporan tahunan yang didapat dari Bursa Efek Indonesia (BEI). Latar penelitian menggunakan jenis non-contrived, untuk mengetahui hubungan sebab dan akibat variable likuiditas, leverage, salesgrowth, ukuran perusahaan, kepemilikan manajerial, dan kepemilikan insitusional terhadap financial distress. 


\section{Populasi dan Sampel}

Populasi penelitian ini sektor industri dasar dan kimia dan sektor industri barang konsumsi yang terdaftar di Bursa Efek Indonesia (BEI) 2009-2018 terdapat 81 perusahaan. Pengambilan sampel menggunakan teknik purposive sampling, sampel tersebut ditarik dari populasi dengan memasukkan dalam kriteria penelitian. Metode purposive sampling merupakan suatu metode untuk pengambilan sampel yang akan disesuaikan dengan kriteriakriteria tertentu (Gunawan \& Wahyuni, 2013). Kriteria-kriteria dalam pengambilan sampel penelitian sebagai berikut:

Tabel 1. Kriteria Pengambilan Sampel

\begin{tabular}{clc}
\hline No & \multicolumn{1}{c}{ Keterangan } & Jumlah \\
\hline 1 & $\begin{array}{l}\text { Perusahaan sektor industri dasar } \\
\text { dan kimia dan sektor industri }\end{array}$ & \\
barang konsumsi yang konsisten & \\
terdaftar di Bursa Efek Indonesia & \\
(BEI) periode 2009-2018 & \\
2 Perusahaan sektor industri dasar & $(7)$ \\
dan kimia dan sektor industri & \\
barang konsumsi yang tidak & \\
konsisten menerbitkan laporan & \\
keuangan periode 2009-2018 & \\
3 Perusahaan sektor industri dasar & $(11)$ \\
dan kimia dan sektor industri & \\
barang konsumsi yang tidak & \\
menggunakan mata uang selain & \\
mata uang rupiah (Rp) periode & \\
2009-2018 & \\
Jumlah sampel tahun 2009-2018 & 63 \\
\hline
\end{tabular}

Sumber: Data diolah penulis (2020)

\section{Operasional Variabel}

\section{a. Rasio Likuiditas}

Rasio likuiditas adalah kemampuan suatu perusahaan untuk memenuhi kewajiban-kewajibannya pada waktu yang tepat (Fahmi, 2014:65). Likuiditas menggambarkan keadaan perusahaan yang memiliki kemampuan untuk membayar kewajiban lancarnya (Kristanti, 2019:19).

\section{Current Ratio $=\frac{\text { Current Assets }}{\text { Current Liabilities }}$}

b. Rasio Leverage

Rasio leverage adalah mengukur sebarapa besar perusahaan dibiayai dengan hutang (Fahmi, 2014:72). Rasio leverage merupakan rasio yang digunakan untuk mengukur kemampuan perusahaan untuk membayar seluruh kewajibannya, baik jangka panjang maupun jangka pendek apabila perusahaan dilikuidasi (Lienanda \& Ekadjaja, 2019).

Debt to Asset Ratio

$$
=\frac{\text { Total Liabilities }}{\text { Total Assets }}
$$

\section{c. Salesgrowth}

Salesgrowth mengukur kemampuan perusahaan untuk mempertahankan posisi ekonominya ditengah pertumbuhan perekonomian dan sektor usahanya (Yudiawati \& Indriani, 2016). Salesgrowth mencerminkan keberhasilan dalam investasi bagi perusahaan di periode tahun sebelumnya dan dijadikan gambaran prediksi untuk periode dimasa depan (Widhiari \& Merkusiwati, 2015).

\section{Salesgrowth}

$$
=\frac{\text { Penjualan }(\mathbf{t})-\text { Penjualan }(\mathbf{t}-\mathbf{1})}{\text { Penjualan }(\mathbf{t}-\mathbf{1})}
$$




\section{d. Ukuran Perusahaan}

Ukuran perusahaan merupakan skala yang mengklasifikasikan besar kecilnya suatu perusahaan (Zhafirah \& Majidah, 2019). Ukuran perusahaan menggambarkan seberapa total asset yang dimiliki perusahaan (Putri \& Merkusiwati, 2014)..

\section{Ukuran Perusahaan $=$ Ln Total Aset}

\section{e. Kepemilikan Manajerial}

Kepemilikan manajerial merupakan proporsi pemegang saham dari manajemen yang secara aktif ikut dalam dalam pengambilan keputusan perusahaan (Pujiati, 2009)

\section{Kepemilikan Manajerial \\ $=\frac{\sum \text { Saham yang dimiliki manajer }}{\sum \text { Saham yang beredar }}$}

\section{f. Kepemilikan Institusional}

Kepemilikan institusional adalah kepemilikan saham oleh lembaga dari eksternal (Cinantya \& Merkusiwati, 2015). Kepemilikan institusional merupakan sama seperti perusahaan asuransi, perusahaan investasi dan kepemilikan institusi lain (Pujiati, 2009).

\section{Kepemilikan Institusional}

$=\frac{\sum \text { Saham yang dimiliki institusional }}{\sum \text { Saham yang beredar }}$

\section{g. Financial Distress}

Menurut Kristanti (2019:7) financial distress merupakan suatu situasi ketika sebuah perusahaan tidak mampu memenuhi kewajibannya, apabila terus berlanjut hal buruk yang akan terjadi perusahaan akan mengalami kebangkrutan. Financial distress adalah keadaan perusahaan dimana memiliki potensi untuk mengalami kebangkrutan karena perusahaan tidak mampu membayar kewajiban-kewajibannya dan menghasilkan laba yang kecil yang memberikan dampak pada perubahan modal sehingga perlu restrukturisasi pada perusahaan yang bersangkutan (Noviandri, 2014)

\section{Metode Analisis Data}

Metode yang analisis data yang digunakan dalam peneltian ialah analisis survival. Analisis survival adalah alat metode statistik untuk menganalisis data pada suatu kejadian dan waktu kejadian. Analisis survival digunakan karena metode ini diketahui lebih akurat dan untuk mengetahui dimana variable mempertahankan kelangsungan hidup sampai periode waktu tertentu atau sebaliknya tidak (Kristanti, Rahayu, et al., 2016). Model analisis survival adalah model yang berkaitan dengan menguji panjang interval waktu antara masa transisi (Antika \& Anggraeni, 2018). Analisis survival adalah model statistika yang digunakan uintuk mengetahui kejadian dan waktu dari peristiwa yang terjadi (Kristanti, Herwany, et al., 2016)

Analisis survival merupakan alat statistika yang berkaitan dengan waktu. Tujuannya adalah untuk mengetahui 
pengaruh terhadap financial distress terhadap waktu kejadian (Kristanti, 2019:53). Tujuan analisis survival adalah untuk mengetahui hubungan antara waktu kelangsungan (survival) dengan variablevariabel yang diduga mempengaruhi waktu survival (Prabawati et al., 2018) Analisis survival dapat dilakukan dengan analisis model regresi Cox proportional hazard. Fungsi hazard merupakan fungsi yang memodelkan probabilitas kegagalan individu. Analisis survival dimulai dari waktu awal hingga kejadian hingga berakhirnya suatu kejadian dengan artian berupa kegagalan atau bertahan (Kristanti, 2019:53). Rumus regresi Cox proportional hazard, sebagai berikut:

Regresi cox proportional hazard sebagai berikut:

$h(t, x)=h_{0}(t) \exp \left(\beta_{1} x_{1}\right)+\left(\beta_{2} x_{2}\right) \ldots+\beta_{p} x_{p}$ Keterangan:

$h(t, x)=$ Fungsri risiko kegagalan individu watu $t$ dengan kejadian $x$

$h_{0}(t) \quad=$ Fungsi hazard dasar

$\beta_{\mathrm{I}} \quad=$ Koefisien regresi

$\mathrm{X}_{1} \quad=$ Likuiditas

$\mathrm{X}_{2} \quad=$ Leverage

$\mathrm{X}_{3} \quad=$ Salesgrowth

$\mathrm{X}_{4} \quad=$ Ukuran Perusahaan

$\mathrm{X}_{5} \quad=$ Kepemilikan Manajerial

$\mathrm{X}_{6} \quad=$ Kepemilikan Institusional

\section{HASIL PENELITIAN DAN}

PEMBAHASAN

\section{Hasil Pengujian Statistik Deskriptif}

Pengujian langkah awal yaitu uji analisis statistik deskriptif. Berdasarkan tabel 1, diketahui bahwa rasio likuiditas memiliki nilai rata-rata 2,811057 , berarti pada sektor tersebut memiliki kemampuan yang cukup besar dalam membiayai kewajiban lancar dari aktiva lancarnya. Nilai minimum sebesar 0,3466, berarti aktiva lancar perusahaan dapat menutupi kewajiban lancarnya 0,3466 kali. Sedangkan untuk nilai maksimumnya sebesar 26,1061, mempunyai arti bahwa aktiva lancar perusahaan dapat menutupi kewajiban lancar sebesar 26 kali. Nilai standar deviasi sebesar 3,6427698 dimana nilai rata-rata lebih kecil daripada standar deviasi yang berarti rasio likuiditas bervariasi dan menyebar disekitar rata-rata.Nilai likuiditas yang tinggi berarti perusahaan memiliki aktiva lancar yang besar dan digunakan untuk melunai kewajiban lancarnya.

Rasio leverage perusahaan sektor industri dasar dan kimia dan sektor industri barang konsumsi yang terdaftar di Bursa Efek Indonesia tahun 2009-2018. Nilai ratarata leverage yaitu 0,469878, berarti perusahaan membiayai operasional perusahaan dengan utang sebesar 46,98\% dari total aset perusahaan. Nilai minimum 


\section{Nominal: Barometer Riset Akuntansi dan Manajemen}

P-ISSN: 2303-2065 E-ISSN: 2502-5430

Volume 9 No 2 (2020)

sebesar 0,0009 berarti kewajiban perusahaan $0,09 \%$ dari total aset yang dimiliki. Nilai maksimum sebesar 2,3331, yang mempunyai arti bahwa $233 \%$ aset perusahaan dibiayai oleh kewajiban perusahaan. Hal ini dapat mengurangi kemampuan perusahaan dalam melunasi seluruh kewajiban perusahaan, karena memiliki nilai yang terlalu tinggi.

Salesgrowth perusahaan sektor industri dasar dan kimia dan sektor industri barang konsumsi yang terdaftar di Bursa Efek Indonesia tahun 2009-2018. Nilai ratarata salesgrowth sebesar 0,065354, yang mempunyai arti bahwa pertumbuhan penjualannya sebesar 6,5\% dari tahun sebelumnya. Pertumbuhan penjualan pada sektor ini masih terlalu kecil hanya 6,5\%. Nilai minimum sebesar -0,2998, artinya pada tahun sebelumnya perusahaan mengalami penurunan penjualan. Nilai maksimum sebesar 1,3725 yang memiliki arti bahwa pada tahun sebelumnya perusahaan memiliki persentase penjualan sebesar $137 \%$.

Ukuran perusahaan pada perusahaan sektor industri dasar dan kimia dan sektor industri barang konsumsi yang terdaftar di Bursa Efek Indonesia tahun 2009-2018. Nilai rata-rata ukuran perusahaan sebesar 28,433586, berarti rata-rata ukuran perusahaan cukup besar yang berarti total aset yang dimiliki perusahaan dapat mempermudah kegiatan operasional perusahaan. Nilai minimun yang diperoleh sebesar 25,7608 yang artinya terdapat perusahaan yang memiliki total aset tidak terlalu tinggi. Nilai maksimum sebesar 32,2010 , yang memiliki arti bahwa terdapat perusahaan memiliki aset yang besar. Hal ini aset yang dimiliki besar dapat meminimalisir risiko kesulitan keuangan dan juga dalam melunasi kewajiban dengan tepat waktu.

Kepemilikan manajerial perusahaan sektor industri dasar dan kimia dan sektor industri barang konsumsi yang terdaftar di Bursa Efek Indonesia tahun 2009-2018. Nilai rata-rata kepemilikan manajerial 0,047631 berarti kepemilikan manajerial yang dimiliki 47\% cukup besar dari keseluruhan saham yang beredar. Nilai minimum sebesar 0,000 berarti terdapat perusahaan yang belum menerapkan kepemilikan manajerial. Nilai maksimum sebesar 0,6828, berarti perusahaan tersebut cukup dikelola oleh $68 \%$ kepemilikan manajerial. Hal ini berarti dalam pengambilan keputusan oleh manajemen diketahui juga oleh pemegang saham.

Kepemilikan institusional perusahaan sektor industri dasar dan kimia dan sektor industri barang konsumsi yang terdaftar di Bursa Efek Indonesia tahun 2009-2018. Nilai rata-rata kepemilikan institusional sebesar 0,812642 , berarti $80 \%$ saham yang beredar dimiliki oleh saham institusional. Nilai minimum sebesar 0,000 , berarti terdapat perusahaan yang belum menerapkan kepemilikan institusional. Nilai maksimum 


\section{Nominal: Barometer Riset Akuntansi dan Manajemen}

P-ISSN: 2303-2065 E-ISSN: 2502-5430

Volume 9 No 2 (2020)

sebesar 9,3782, berarti terdapat perusahaan yang sahamnya dimiliki oleh institusional atau lembaga eksternal perusahaan sebesar 93\%. Hal ini dapat memperketat pengawasan serta pengambilan keputusan bagi perusahaan.

Tabel 2. Hasil Uji Statistik Deskriptif

\begin{tabular}{lccccc}
\hline & $\mathbf{N}$ & Min & Max & Mean & Std. Dev \\
\hline $\mathrm{t}$ & 63 & 1.0 & 10.0 & 8.079 & 2.8698 \\
Eve & 63 & .0 & 1.0 & .508 & .5040 \\
$n t$ & & & & & \\
$\mathrm{LI}$ & 6 & .3466 & 26.10 & 2.81105 & 3.64276 \\
$\mathrm{~K}$ & 3 & & 61 & 7 & 98 \\
$L E$ & 6 & .0009 & 2.333 & .469878 & .332965 \\
$V$ & 3 & & 1 & & 7 \\
$S G$ & 6 & - & 1.372 & .065354 & .210559 \\
& 3 & .2998 & 5 & & 5 \\
$S I Z$ & 6 & 25.76 & 32.20 & 28.4335 & 1.66669 \\
$E$ & 3 & 08 & 10 & 86 & 32 \\
$\mathrm{~K}$ & 6 & .0000 & .6828 & .047631 & .123633 \\
$\mathrm{M}$ & 3 & & & 0 \\
$\mathrm{KI}$ & 6 & .0000 & 9.378 & .812642 & 1.15591 \\
& 3 & \multicolumn{5}{c}{ Sumber: Output SPSS 23 }
\end{tabular}

\section{Pengujian Hipotesis}

\section{Pengujian Hipotesis Simultan (Uji F)}

Pengujian simultan ini dilakukan untuk mengetahui kaitan antar variabel independen $(\mathrm{X})$ terhadap variabel dependen (Y) dengan uji Chi-square. Uji Chi-square dengan nilai signifikansi 0,05 . Jika nilai probabilitasnya kurang dari 0,05 ( $p$-value < $0,05)$ berati $\mathrm{H}_{0}$ ditolak sehingga kaitan pengaruh antar variabel independen terhadap variabel dependen berpengaruh pada financial distress secara simultan konsumsi, sebagai berikut:

Pada tabel 3 menujukkan hasil dari omnibus test. Dapat dilihat nilai -2 Log
Likelihood 227.226, nilai Chi-square 28.755, dan nilai probabilitasnya (Sig) 0.000 . Dari hasil tersebut $0.000<0,005$ model dikatakan fit. Variabel independen yaitu likuiditas, leverage, salesgrowth, ukuran perusahaan, kepemilikan manajerial dan kepemilikan institusional dapat mempengaruhi financial distress dengan signifikan.

Tabel 3. Hasil Uji Simultan Omnibus Test

\begin{tabular}{cccc}
\hline $\begin{array}{c}-2 \text { Log } \\
\text { Likelihood }\end{array}$ & $\begin{array}{c}\text { Chi- } \\
\text { square }\end{array}$ & Df & Sig. \\
\hline 227.226 & 28.755 & 6 & .000 \\
\hline \multicolumn{4}{c}{ Sumber: Output SPSS 23} \\
\hline
\end{tabular}

\section{Pengujian Hipotesis Parsial (Uji T)}

Pengujian parsial dalam penelitian dengan uji wald. Pengujian parsial diketahui guna mengetahui setiap variabel independen memiliki pengaruh pada variabel dependen. Melihat pengaruh tersebut menggunakan nilai signifikansi 0,05 . Jika nilai probabilitasnya kurang dari 0,05 ( $p$-value < $0,05)$ maka $\mathrm{H}_{0}$ ditolak sehingga terdapat hubungan pengaruh antar variabel independen terhadap variabel dependen. Berikut hasil pengujian uji hipotesis parsial sebagai berikut:

Tabel 4. Hasil Uji Parsial Uji Wald

\begin{tabular}{ccccccc}
\hline Variable & B & SE & Wald & Df & Sig. & $\operatorname{Exp}(\mathbf{B})$ \\
\hline LIK & .019 & .113 & .029 & 1 & .864 & 1.019 \\
LEV & .043 & .321 & .018 & 1 & .893 & 1.044 \\
SG & -.924 & .373 & 6.130 & 1 & .013 & .397 \\
SIZE & -.074 & .031 & 5.542 & 1 & .019 & .929 \\
KM & 1.694 & 1.324 & 1.639 & 1 & .200 & 5.444 \\
KI & .258 & .122 & 4.505 & 1 & .034 & 1.294 \\
\hline
\end{tabular}

Sumber: Output SPSS 23 


\section{Nominal: Barometer Riset Akuntansi dan Manajemen}

P-ISSN: 2303-2065 E-ISSN: 2502-5430

Volume 9 No 2 (2020)

Berikut penjelasan hasil uji Wald pada setiap variabel:

1. Likuiditas

Likuiditas memiliki koefisien positif 0,019, nilai probabilitasnya sebesar 0,864 . 0,0864>0,05 yang berarti $\mathrm{H}_{0}$ diterima. Likuiditas tidak dapat mempengaruhi financial distress karena memiliki nilai probabilitas yang lebih dari nilai signifikansi 0,05 dan hasil penelitian yang dilakukan tidak sama dengan hipotesis penelitian.

2. Leverage

Leverage memiliki koefisien positif 0,043 , nilai probabilitasnya sebesar 0,893 . $0,0893>0,05$ yang berarti $\mathrm{H}_{0}$ diterima. Leverage tidak dapat mempengaruhi financial distress karena nilai p-value yang lebih besar dari nilai signifikansinya dan hasil penelitian tidak sama dengan hipotesis penelitian.

3. Salesgrowth

Salesgrowth memiliki nilai koefisien sebesar $-0,924$ arah negatif, sementara nilai probabilitasnya sebesar 0,013. $0,013<0,05$ yang berarti $\mathrm{H}_{0}$ ditolak. Hasil tersebut sejalan dengan hipotesis penelitian, yang menyatakan bahwa salesgrowth dapat mempengaruhi financial distress dengan arah negatif dan signifikan.

4. Ukuran Perusahaan

Ukuran perusahaan memiliki nilai koefisien -0.074, dan nilai probabilitasnya 0,019. 0,019<0,05 artinya $\mathrm{H}_{0}$ ditolak. Hasil uji wald sejalan dengan hipotesis penelitian yang menyatakan ukuran perusahaan mempengaruhi financial distress secara signifikan dengan arah negatif.

\section{Kepemilikan Manajerial}

Kepemilikan manajerial memiliki nilai koefisien 1,694, dan nilai probabilitasnya sebesar 0,200. 0,200 >0,05 yang berarti $\mathrm{H}_{0}$ diterima. Hasil uji wald tidak sejalan dengan hipotesis penelitian, sehingga kepemilikan manajerial tidak dapat mempengaruhi financial distress.

6. Kepemilikan Institusional

Kepemilikan institusional memiliki koefisien 0,258 , nilai probabilitasnya sebesar 0,034. $0,034<0,05$ yang berarti $\mathrm{H}_{0}$ ditolak. Hasil uji wald sejalan dengan hipotesis penelitian yang menyatakan kepemilikan institusional dapat mempengaruhi financial distress secara signifikan, tetapi dengan arah yang berbeda yaitu positif.

\section{Model Persamaan Analisis Survival}

Berdasarkan tabel 4 hasil yang diperoleh pengujian parsial regresi cox proportional hazard maka diperoleh model sebagai berikut:

$$
\begin{gathered}
\mathrm{h}(\mathrm{t}, \mathrm{x})=\mathrm{h}_{0}(\mathrm{t}) \exp (0,019 \mathrm{LIK}+0,043 \mathrm{LEV}- \\
\text { 0,924SG-0,074SIZE+1.694KM+0,258KI })
\end{gathered}
$$

Keterangan:

$h(t, x)=$ Fungsri risiko kegagalan individu watu $t$ dengan kejadian $x$

$h_{0}(t) \quad=$ Fungsi hazard dasar

$\beta_{\mathrm{I}} \quad=$ Koefisien regresi 


$$
\begin{array}{ll}
\text { LIK } & =\text { Likuiditas } \\
\text { LEV } & =\text { Leverage } \\
\text { SG } & =\text { Salesgrowth } \\
\text { SIZE } & =\text { Ukuran Perusahaan } \\
\text { KM } & =\text { Kepemilikan Manajerial } \\
\text { KI } & =\text { Kepemilikan Institusional }
\end{array}
$$

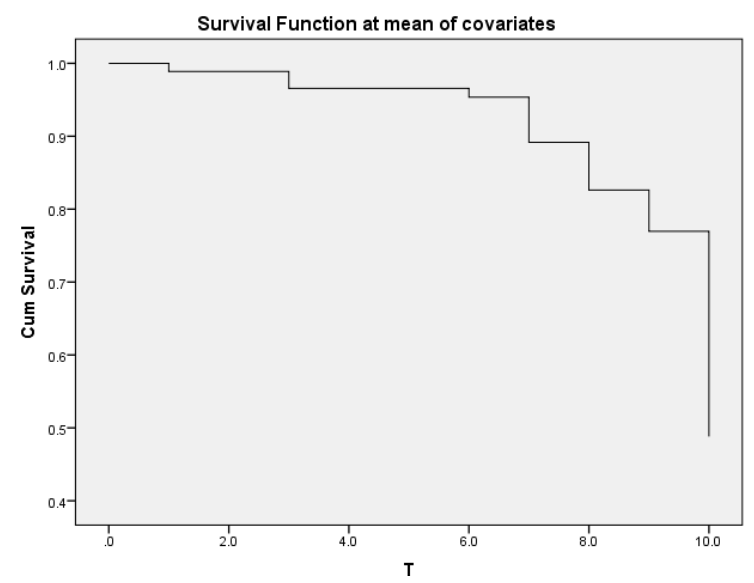

Gambar 3. Survival Function Pada Perusahaan

Sektor Industri Dasar Kimia Dan Sektor Industri Barang Konsumsi Yang Terdaftar Di Bursa Efek Indonesia (BEI) Periode 2009-2018.

Pada gambar 3, dijelaskan bahwa garis kelangsungan hidup perusahaan sektor industri dasar dan kimia dan industri barang konsumsi yang terdaftar di Bursa Efek Indonesia (BEI) tahun 2009-2018. Dari gambar tersebut, dari tahun pertama hingga tahun kesepuluh pada grafik tersebut mengalami penurunan yang berarti pada tahun ke sepuluh hingga tahun selanjutnya perusahaan semakin mengecil atau menurun kemungkinan perusahaan mengalami financial distress.

\section{Pembahasan}

\section{Likuiditas Terhadap Financial Distress}

Berdasarkan tabel 3, rasio likuiditas memiliki nilai probabilitas 0,0864 nilai tersebut lebih besar dari nilai signifikansi 0,05. Dapat disimpulkan bahwa rasio likuiditas tidak berpengaruh terhadap financial distress pada perusahaan sektor industri dasar kimia dan sektor industri barang konsumsi yang terdaftar di Bursa Efek Indonesia (BEI) periode 2009-2018. Hasil ini memiliki kesamaan dengan Nurcahyono dan Sudharma (2014) dan yang menyebutkan bahwa likuiditas tidak dapat memiliki pengaruh terhadap kondisi financial distress. Likuiditas menunjukkan kemampuan perusahaan dalam menyelesaikan kewajiban jangka pendek pada waktu yang tepat. Hasil penelitian tidak sesuai sama hipotesis penelitian. Hal ini berarti kinerja manajemen perusahaan dikatakan baik karena memiliki kemampuan dalam melunasi kewajiban pendeknya dengan aktiva jangka pendeknya pada saat waktu jatuh tempo.

\section{Leverage Terhadap Financial Distress}

Berdasarkan tabel 3, leverage memiliki nilai probabilitas yang lebih besar daro 0,05 yaitu 0,893 dan memiliki nilai koefisien positif 0,043. Dapat disimpulkan bahwa leverage tidak berpengaruh terhadap financial distress pada perusahaan sektor 


\section{Nominal: Barometer Riset Akuntansi dan Manajemen}

P-ISSN: 2303-2065 E-ISSN: 2502-5430

Volume 9 No 2 (2020)

industri dasar kimia dan sektor industri barang konsumsi yang terdaftar di Bursa Efek Indonesia (BEI) periode 2009-2018. Hasil ini sejalan dengan Aisyah, Kristanti, dan Zultilisna (2017) yang menunjukkan hasil leverage yang tidak terdapat pengaruh signifikan terhadap financial distress. Hasil penelitian tidak sesuai sama hipotesis penelitian. Leverage berguna untuk melihat seberapa besar kemampuan perusahaan dalam melunasi seluruh kewajiban perusahaan. Perusahaan yang memiliki total kewajiban besar dan memiliki risiko gagal bayar, belum dikategorikan financial distress karena kemungkinan dalam melunasi kewajiban tersebut menggunakan modal yang dimiliki perusahaan sehingga peluang financial distress mengecil.

\section{Salesgrowth Terhadap Financial Distress}

Berdasarkan tabel 3, salesgrowth memiliki nilai probabilitas atau p-value $0,013<0,05$ dan memiliki nilai koefisien negatif sebesar $-0,924$. Dapat disimpulkan bahwa salesgrowth dapat mempengaruhi dengan arah negatif terhadap financial distress pada perusahaan sektor industri dasar kimia dan sektor industri barang konsumsi yang terdaftar di Bursa Efek Indonesia (BEI) periode 2009-2018. Hasil ini sejalan dengan hipotesis penelitian dan hasil ini memiliki kesamaan dengan Yudiawati dan Indriani (2016) yang mengatakan salesgrowth memiliki pengaruh dengan arah negative terhadap financial distress. Salesgrowth menggambarkan persentase penjualan dari tahun ke tahun bagi perusahaan. Semakin tinggi salesgrowth maka mengurangi kemungkinan terjadinya financial distress. Meningkatnya salesgrowth menunjukkan keberhasilan perusahaan dalam memasarkan serta menjualkan produk yang dihasilkan dan perusahaan akan memperoleh laba yang meningkat (Widarjo \& Setiawan, 2009). Besarnya laba yang diperoleh perusahaan diharapakan dapat mempertahankan keberlangsungan perusahaan untuk terhindar dari financial distress.

\section{Ukuran Perusahaan Terhadap Financial} Distress

Berdasarkan tabel 3, ukuran perusahaan memiliki nilai probabilitas lebih kecil dari nilai signifikansi 0,05 yaitu sebesar 0,019 dan memiliki nilai koefisien negatif sebesar -0.074. Dapat disimpulkan bahwa ukuran perusahaan berpengaruh dengan arah negatif terhadap financial distress pada perusahaan sektor industri dasar kimia dan sektor industri barang konsumsi yang terdaftar di Bursa Efek Indonesia (BEI) periode 2009-2018. Hasil ini sejalan dengan hipotesis penelitian dan hasil ini memilki kesamaan dengan Kristanti dan Effendi (2017) yang mengatakan ukuran perusahaan 
berpengaruh arah negatif signifikan terhadap financial distress Mengetahui ukuran perusahaan dapat dilihat pada total aktiva. Total aktiva yang besar yang dimiliki perusahaan berarti perusahaan memiliki kemampuan dalam melunasi kewajiban diperiode yang akan datang dan dapat mempertahankan keberlangsungan perusahahaan. Semakin besar ukuran perusahaan maka semakin mengecil kemungkinan financial distress.

\section{Kepemilikan Manajerial Terhadap} Financial Distress

Berdasarkan tabel 3, kepemilikan manajerial memiliki nilai probabilitas sebesar 0,200 > 0,05. Dapat disimpulkan bahwa kepemilikan manajerial tidak dapat mempengaruhi financial distress pada perusahaan sektor industri dasar kimia dan sektor industri barang konsumsi yang terdaftar di Bursa Efek Indonesia (BEI) periode 2009-2018. Hasil ini sejalan dengan hipotesis penelitian dan hasil ini sejalan dengan Widyasaputri (2012). Kepemilikan manajerial ialah saham yang dapat dimiliki oleh manajer pada perusahaan tersebut sehingga manajer dikatakan sebagai pemegang saham juga. Besar atau kecilnya kepemilikan saham tersebut tidak dapat mempengaruhi financial distress bagi perusahaan. Hal ini disebabkan kepemilikan saham oleh manajerial merupakan symbolic yang digunakan agar para investor tertarik (Cinantya \& Merkusiwati, 2015).

\section{Kepemilikan Insitusional Terhadap}

\section{Financial Distress}

Berdasarkan tabel 3, kepemilikan institusional memiliki nilai nilai probabilitas 0,034 nilai tersebut lebih kecil dari nilai signifikansi sebesar 0,05 dan memiliki nilai koefisien positif sebesar 0,258. Dapat disimpulkan bahwa kepemilikan institusional dapat mempengaruhi financial distress dengan arah positif pada perusahaan sektor industri dasar kimia dan sektor industri barang konsumsi yang terdaftar di Bursa Efek Indonesia (BEI). Hal ini sejalan dengan penelitian Aritonang (2013), hasil ini tidak sama hipotesis penelitian yang menyatakan kepemilikan institusional berpengaruh signifikan dengan arah negatif. Kepemilikan saham oleh instiusional yang besar dapat mengakibatkan perusahaan mengalami financial distress, dikarenakan manajemen perusahaan berpendapat tidak dapat menutup kerugian yang terjadi di perusahaan (Aritonang, 2013).

\section{SIMPULAN DAN SARAN}

Penelitian ini memperoleh hasil penelitian secara simultan bahwa variabel likuiditas, leverage, salesgrowth, ukuran perusahaan, kepemilikan manajerial dan kepemilikan institusional memiliki hubungan pengaruh terhadap financial distress. 
Sedangkan secara parsial, variabel salesgrowth dan ukuran perusahaan memiliki pengaruh yang signifikan arah negatif terhadap financial distress sementara kepemilikan institusional memiliki pengaruh yang signifikan arah positif terhadap financial distress. Variabel likuiditas, leverage, dan kepemilikan manajerial tidak memiliki pengaruh terhadap financial distress.

Disarankan untuk penelitian selanjutnya dengan financial distress untuk menambahkan variabel diluar variable yang diteliti oleh penulis seperti operating profit margin, corruption, cash flow, capital intensity, konsentrasi kepemilikan komisaris atau dewan, umur perusahaan, gender diversity pada penelitiannya karena untuk lebih memperdalam penyebab yang sebenarnya dapat mempengaruhi financial distress. Penelitian selanjutnya juga diharapkan meneliti pada sektor lain yang terdaftar di Bursa Efek Indonesia (BEI).

\section{DAFTAR PUSTAKA}

Aisyah, N. N., Kristanti, F. T., \& Zultilisna, D. (2017). Pengaruh Rasio Likuiditas, Rasio Aktivitas, Rasio Profitabilitas, Dan Rasio Leverage Terhadap Financial Distress (Studi Kasus Pada Perusahaan Tekstil Dan Garmen Yang Terdaftar Di Bursa Efek Indonesia Tahun 20112015). E-Proceeding Of Management, 4(1), 411-419.

Antika, D. P., \& Anggraeni, D. (2018). Analisis Hubungan Antara Financial
Distress Dan Keputusan Kebijakan Dividen Omisi Perusahaan Manufaktur. Journal Math And Its Appl, 15(1), 4154.

Https://Doi.Org/10.12962/Limits.V15i 1.3390

Aritonang, A. P. (2013). Pengaruh Praktik Corporate Governance Dan Struktur Kepemilikan Terhadap Kemungkinan Kondisi Financial Distress Perusahaan. Jurnal Media Riset Uiversitas Bakrie, 3(2), 105-124.

Carolina, V., Marpaung, E. L., \& Pratama, D. (2017). Analisis Rasio Keuangan Untuk Memprediksi Kondisi Financial Distress (Studi Empiris Pada Perusahaan Manufaktur Yang Terdaftar Di Bursa Efek Indonesia Periode 20142015). Jurnal Akuntansi Maranatha, 9(2), 137-145.

Cinantya, I. G. A. A. ., \& Merkusiwati, N. K. L. . (2015). Pengaruh Corporate Governance Financial Indikator Dan Ukuran Perusahaan Pada Financial Distress. Jurnal Akuntansi Universitas Udayana, 10(3), 897-915. Https://Doi.Org/10.3(2015)

Fahmi, I. (2014). Pengantar Manajemen Keuangan. Alfabeta.

Gobenvy, O. (2014). Pengaruh Profitabilitas, Financial Leverage Dan Ukuran Perusahaan Terhadap Financial Distress Pada Perusahaan Manufaktur Yang Terdaftar Di Bursa Efek Indonesia Tahun 2009-2011. Jurnal Akuntansi Universitas Negeri Semarang, 2(1), 122.

Gudono. (2017). Teori Organisasi Edisi 4. Penerbit Andi.

Gunawan, A., \& Wahyuni, S. F. (2013). Pengaruh Rasio Keuangan Terhadap Pertumbuhan Laba Pada Perusahaan Perdagangan Di Indonesia. Jurnal Manajemen \& Bisnis, 13(1), 63-84. 
Https://Doi.Org/Https://Doi.Org/10.305 96/Jimb.V13i1.102

Halim, A., Hanafi, M., \& M. (2018). Analisis Laporan Keuangan. Upp Stim Ykpn.

Hari, N. C., Komalig, H., \& Langi, Y. A. (2018). Analisis Survival Dalam Menentukan Faktor-Faktor Yang Mempengaruhi Lama Studi Mahasiswa Matematika Di Jurusan Matematika Fmipa Universitas Sam Ratulangi Manado. Jurnal Matematika Dan Aplikasi Decartesia, 7(1), 84-89.

Jensen, M. C., \& Meckling, W. H. (1976). Theory Of The Firm: Managerial Behavior, Agency Costs And Ownership Structure. Journal Of Financial Economics, 3, 305-360.

Kristanti, F. T. (2019). Financial Distress (1st Ed.). Intelegensia Media.

Kristanti, F. T., \& Effendi, N. (2017). A Survival Analysis Of Indonesian Distressed Company Using Cox Hazard Model. International Journal of Economics And Management Journal Homepage, 11(S1), 155-167.

Kristanti, F. T., Herwany, A., \& Febrian, E. (2016). Does Corporate Governance Affect The Financial Distress Of Indonesian Company? A Survival Analysis Using Cox Hazard Model With Time-Dependent Covariates. Advanced Science Letters, 22, 43264329.

Https://Doi.Org/10.1166/Asl.2016.813 8

Kristanti, F. T., Rahayu, S., \& Huda, A. N. (2016). The Determinant Of Financial Distress On Indonesia Family Firm. 3rd Global Conference On Business And Social Science, 440-447. Https://Doi.Org/10.1016/J.Sbspro.2016 .05 .018

Lienanda, J., \& Ekadjaja, A. (2019). Faktor
Yang Mempengaruhi Financial Distress Pada Perusahaan Manufaktur Yang Terdaftar Di Bei. Jurnal Multiparadigma Akuntansi, 1(4), 10411048.

Moleong, L. C. (2018). Pengaruh Real Interest Rate Dan Leverage Terhadap Financial Distress. Modus, 30(1), 7186.

Https://Doi.Org/Https://Doi.Org/10.240 02/Modus.V30i1.1588

Noviandri, T. (2014). Tio Noviandri; Peranan Analisis Rasio ... Jurnal Ilmu Manajemen. Jurnal Ilmu Manajemen, 2 , 1655-1665.

Prabawati, S., Novia Nasution, Y., \& Wahyuningsih, D. S. (2018). Analisis Survival Data Kejadian Bersama Dengan Pendekatan Efron Partial Likelihood (Studi Kasus: Lama Masa Studi Mahasiswa Fakultas Matematika Dan Ilmu Pengetahuan Alam Universitas Mulawarman Angkatan 2011). Jurnal Eksponensial, 9(1).

Pujiati, D. (2009). Pengaruh Struktur Kepemilikan Terhadap Nilai Perusahaan: Keputusan Keuangan Sebagai Variabel Intervening. Jurnal Ekonomi Bisnis \& Akuntansi Ventura, 12(1), 71-86.

Putri, N. W. K. A., \& Merkusiwati, N. A. K. L. (2014). Pengaruh Mekanisme Corporate Governance, Likuiditas, Leverage, Dan Ukuran Perusahaan Pada Financial Distress. E-Jurnal Akuntansi Universitas Udayana, 7(1), 93-106.

Sudaryono. (2017). Metodologi Penelitian. Pt Raja Grafindo Persada.

Sunarwijaya, I. K. (2017). Pengaruh Likuiditas, Leverage, Kepemilikan Manajerial Dan Kepemilikan Institusional Terhadap Kemungkinan Terjadinya Financial Distress. Jurnal Ekonomi Universitas Mahasaraswati 
Denpasar, 7(1), 1-16.

Widarjo, W., \& Setiawan, D. (2009). Pengaruh Rasio Keuangan Terhadap Kondisi Financial Distress Perusahaan Otomotif. Jurnal Bisnis Dan Akuntansi, 11(2), 107-119.

Widhiari, N. L. M. A., \& Merkusiwati, N. K. A. L. (2015). Pengaruh Rasio Likuiditas, Leverage, Operating Capacity, Dan Sales Growth Terhadap Financial Distress. . . E-Jurnal Akuntansi Universitas Udayana, 11(2), 456-469,.

Yudiawati, R., \& Indriani, A. (2016). Analisis Pengaruh Current Ratio, Debt To Total Asset Ratio, Total Asset Turnover, Dan Sales Growth Ratio Terhadap Kondisi Financial Distress Pada Perusahaan Manufaktur. Diponegoro Journal of Management, 5(2), 1-13.

Zhafirah, A., \& Majidah, \&. (2019). Analisis Determinan Financial Distress (Studi Empiris Pada Perusahaan Subsektor Tekstil Dan Garmen Periode 20132017). Jurnal Riset Akuntansi Dan Keuangan, 7(1), 195-202. Https://Doi.Org/10.17509/Jrak.V7i1.15 497 